\title{
Hepatitis A Surface Antibody Measurement
}

National Cancer Institute

\section{Source}

National Cancer Institute. Hepatitis A Surface Antibody Measurement. NCI Thesaurus.

Code $C 74710$

The determination of the surface antibody reaction of a sample to the Hepatitis A virus. 